Uluslararası Sosyal Bilgilerde Yeni Yaklaşımlar Dergisi, 2021, 5(2), 426-438

International Journal of New Approaches in Social Studies, 2021, 5(2), 426-438

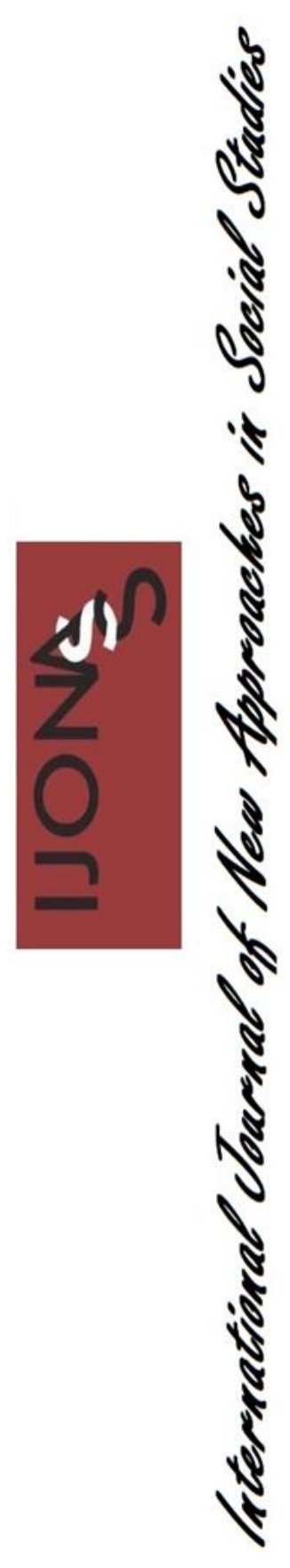

\title{
Development of Perceived Social Justice in Education Scale for Primary School Students
}

\author{
Çiğdem KARAKOÇ ${ }^{1 *}$ (D) \& Gönül SAKIZ ${ }^{2}$ (D)
}

Received: 15 October 2021

Accepted: 18 November 2021

DOI: $10.38015 /$ sbyy. 1010070

\begin{abstract}
:
The purpose of this research was to develop a valid and reliable scale for measuring perceived social justice of the primary school students in educational environments. A descriptive survey design was used. The data was collected from 475 fourth-grade students studying at five primary schools in Istanbul, Turkey. During the scale development, the following steps were taken: (1) The existing literature was reviewed and elementary school teachers' opinions were gathered; (2) a draft scale was developed and the experts' opinions were obtained; (3) the scale with 39 items was applied to 20 students for clarity, comprehensibility and applicability purposes; (4) the actual data was collected in two phases with the participation of 150 and 325 fourthgrade students, respectively; (5) Exploratory and confirmatory factor analyses were conducted. The preliminary analysis showed that the value of Kaiser-Meyer-Olkin was .77 and the Bartlett's sphericity test was statistically significant. The results of the exploratory factor analysis (EFA) revealed a 3-factor structure with 13 items, explaining $52 \%$ of the total variance. The factors, compatible with the literature, were named as participatory justice, recognitional justice and distributive justice. The results of the first and the second order confirmatory factor analysis (CFA) were satisfactory ( $\chi^{2 / d f:} 1.89$ and $\chi^{2 / d f}: 1.86$, respectively). The internal consistency reliability of the overall scale was.78. Finally, a valid and reliable 3-factor, 13 statements instrument, called Perceived Social Justice in Education Scale (PSJES) was developed. The use of this instrument in future related studies would hopefully shed light on the social justice dynamics in classrooms and their impacts on students' academic, behavioural and social-emotional outcomes.
\end{abstract}

Keywords: Social justice in education, primary school, scale development, 2023 Education Vision.

$\ddot{O} z:$

Bu araştırmanın amacı, ilkokul ögrencilerinin eğitimdeki sosyal adalet algılarını ölçen geçerli ve güvenilir bir ölçek geliştirmektir. Çalışmada bir nicel araştırma yöntemi olan betimsel tarama modeli kullanılmıştır. Veriler İstanbul'da bulunan beş ilkokuldaki 475 dördüncü sinıf öğrencisinden toplanmıştır. Ölçek geliştirme sürecinde, şu adımlar izlenmiştir: (1) Illgili alanyazın gözden geçirilmiş ve sınıf öğretmenlerinin görüşleri

\footnotetext{
Cited:

Karakoç, Ç. \& Sakız, G. (2021) Development of perceived social justice in education scale for primary school students. International Journal of New Approaches in Social Studies, 5(2), 426-438. https://doi.org/110.38015/sbyy.1010070
}

\footnotetext{
${ }^{1}$ Marmara University, Turkey. Orcid ID: 0000-0002-4760-734X

${ }^{2}$ Marmara University, Turkey. Orcid ID: 0000-0002-7095-9554

*Corresponding Author: cigdemkarakoc@hotmail.com.tr
} 
alınmıştır; (2) taslak ölçek geliş̧tirilerek uzman görüş̧leri alınmıştır; (3) 39 maddeden oluşan ölçek, açıkllk, anlaşıllırlı ve uygulanabilirlik kontrolü amacıyla 20 öğrenciye uygulanmştır; (4) Veriler iki aşamada, sirastyla, 150 ve 325 dördüncü sinıf öğrencisinin katılımıyla toplanmıştır; (5) Açımlayıcı ve doğrulayıcı faktör analizleri yapılmış̧ır. Kaiser-Meyer-Olkin ölçüm değeri .77 olup Bartlett testi anlamlıdır. Açımlayıcı faktör analizi (EFA) sonuçları, toplam varyansı \%52 düzeyinde açıklayan 3 faktörlü ve 13 maddelik bir ölçek ortaya koymuştur. Faktörler alanyazın ile uyumlu olarak katılımcı adalet, tanıyıcı adalet ve dağıtıcı adalet olarak isimlendirilmişstir. Birinci ve ikinci derece CFA (sırasıyla $\chi^{2}$ / df: 1.89 ve $\chi^{2}$ / df: 1.86) ölçeğin geçerliğini doğrulamıştır. Ölçeğin güvenirliği .78 olarak bulunmuştur. Sonuçta, İlkokul Öğrencileri için Eğitimde Sosyal Adalet Algısı Ölçeği (ESA) adı verilen, 3 faktörlü ve 13 maddelik geçerli ve güvenilir bir ölçek geliş̧tirilmiştir. Bu ölçeğin ileride yapılacak iliş̧ili araş̧ırmalarda kullanımının sınıf ortamında sosyal adalet dinamikleri ve bunların öğrencilerin akademik, davranışsal ve sosyal-duygusal gelişim süreçleri üzerindeki etkileri üzerine ışık tutması beklenmektedir.

Anahtar Kelimeler: Ĕgitimde sosyal adalet, ilkokul, ölçek geliştirme, 2023 Eğitim Vizyonu.

\section{INTRODUCTION}

Social justice has recently gained close consideration in educational policy area. Its urgency is guided by many reasons, including the increasing diversity of school populations, documentations of the differences in achievement scores and economic gaps between children, the dissemination of social injustice analysis and the need to prepare children to participate in the democratic process for a multicultural society (Bates, 2006; Furman \& Shields, 2005). The concept of social justice in education has become more important in Turkey with the publication of the Education Vision 2023 document including a goal of raising individuals acquiring the 21 st century skills and can use those skills for the benefit of humanity. One of the goals to be achieved in this process is to create a fair and human-centred understanding in education (Turkish Ministry of National Education, 2018).

Social justice refers to the degree to which a society supports what is necessary for a good life rather than a fair distribution of resources such as income and wealth among individuals within a community; these refer to the use and development of a person's talents, to reveal and express their experience, to adopt free will and to support self-development for all (Speight \& Vera, 2004). Social justice is focused on the division of the social product within a complex division of labour (Johnston, 2011). Social justice is connected to how benefits and deficits are allocated to individuals in community (Miller, 1999).

OECD (2012), encourages efforts to reduce the discrimination among schools in which students with different cultural and socio-economic status continue their education for both fair and economically efficient educational environments. In this context, social justice in education is about preparing individuals for democratic participation and supporting access to education services (Furman \& Shields, 2005).

The social justice theory in education has three dimensions, including political dimension of representation, cultural dimension of recognition and economic dimension of distribution (Fraser, 2007). Social justice in education consists of three sub-dimensions which are participatory justice, recognitional justice and distributive justice (Bates, 2006; Fraser, 2001; Karacan et al., 2015).

The distributive justice refers to who gets how much of social good such as money, welfare, and education. Providing elementary school education for the whole population, fair access to 
higher education or free textbooks for all students are several examples for distributive justice, underlying the necessity of benefiting from equal resources (Connel, 1993).

Recognitional justice demands recognition, respect and understanding of cultural diversity and recognition, considered as a foundation of social justice, would involve a positive affirmation of the cultural practices of oppressed groups (Bates, 2006). Kolucki and Lemish (2011), proposes to reflect the value of each child and support all kinds of diversity with an inclusive approach. United Nations Convention on the Rights of the Child ensures the rights of children to develop cultural identity and to be honoured with their cultural values and beliefs (United Nations, 2006). Similarly, United Nations Convention on the Rights of Persons with Disabilities (United Nations, 2006) emphasizes that the holistic development of human and the strengthening of respect for human diversity, fundamental freedoms and rights should be encouraged by education.

Participatory justice can be explained by the concept of democracy in education. Hunt (1998) draws attention to the existence of social justice at the centre of democratic education (Tomul, 2009). Formal education is important for constructing democracy culture among students and democratic teachers should have values and attitudes including justice and liberty (Uluçınar \& Aypay, 2018). Democratization of classroom practices plays an important role in eliminating unfair situations that make a difference between students (Giroux, 1992). With increased exclusion and reduced participation in learning, subsequent decreases in performance occur and performance differences between advantageous and disadvantaged groups increase (Bates, 2006; Wrigley, 2003, Wrigley 2004). Students in social and learning environments can play an active role in making decisions and expressing themselves by participating in discussions with their knowledge, value, experience and perspective.

Social justice is possible with institutional arrangements that contribute to the social welfare of each individual (Miller, 1999). In their study, Koçak and Bostanc1 (2019), emphasized the need for students to adopt an approach that, in schools, no group is superior to another. Teachers, in that study, expressed the necessity of creating a school culture where respect for differences is the main factor. In their research, Furman and Shields (2005) emphasized the need for creating a democratic classroom environment for increasing students' academic success. Social justice is associated not only with academic success but also with emotional variables. For example, some researchers have theorized a relation between hope and social justice (Sandage et al., 2014). The related literature continually reveals a link among students' perceptions of social justice in education and their social, emotional and academic developments in educational environments. Therefore, schools and teachers are expected to be actively involved in the development of social justice perception (Cochran-Smith, 2004). Also, teachers should increase their students' success and prepare them for a democratic society (Furman \& Shields 2005).

It is vital for primary school teachers to provide foresight about how to maintain positive student perceptions related to educational social justice implementations and how to prevent students' negative perceptions in the classroom. The literature shows that the social justice is dominantly examined within education administration field. Also, a scale that can measure high school teachers' level of performing social justice in schools validly and reliably has been found in the literature (Karacan et al., 2015). However, to our knowledge, there has not been any research inquiring this concept from the perception of primary school students and no related scale developed at this level so far. Therefore, the purpose of this study was to develop a valid and reliable scale to measure primary school students' perceived social justice in educational 
environments. The developed scale is expected to provide a better understanding of students' perceptions of social justice in primary education and contribute to the identification of the factors causing and affecting primary school students' perceived social justice in education. The related studies which would result from the use of this scale would hopefully help educational leaders and teachers to design educational environments, plan curriculums and activities, shape attitudes considering the necessities of social justice. Considering the potential increase of research within this scope, the scale would also contribute to the literatures of primary school education and social justice.

\section{METHOD}

\section{Participants}

The study was conducted with three sampling groups of fourth-grade students attending five elementary schools in Istanbul in the academic year of 2018-2019. The participating schools were chosen based on the convenient sampling method. The first group of participants, consisted of 20 students, provided information related to the comprehensibility, applicability and usefulness of the scale. Other two sampling groups were used for the purpose of the exploratory and the confirmatory factor analyses. In the first application, there were 150 fourthgrade students while in the second application, there were 325 fourth-grade students (Table 1).

Table 1. Descriptive Statistics of the Participants

\begin{tabular}{lrrrrrl}
\hline \multirow{2}{*}{ Sample } & \multicolumn{2}{c}{ Male } & \multicolumn{2}{c}{ Female } & \multirow{2}{*}{ Total } \\
\hline EFA Sample & $f$ & $\%$ & $f$ & $\%$ & 150 \\
CFA Sample & 71 & 47.3 & 79 & 52.7 & 325 \\
\hline
\end{tabular}

\section{Instrument Development}

In this study, a descriptive survey design was used to develop Perceived Social Justice in Education Scale (PSJES). Each stage of the instrument development was explained in order below:

First stage: During the item development procedure, first, the literature on social justice in education was investigated (Furman \& Shields, 2005; Kocak \& Bostanc1; 2019; Miller, 1999; Tomul, 2009) and, also, primary school teachers' and students' opinions on social justice were gathered. Based on the data, a draft item pool was created. Considering the target group's developmental level, the items were written in short sentences, as clearly as possible. During the item development stage, national and international literature such as UNICEF, United Nations Convention on the Rights of the Child, OECD and Ministry of National Education (MEB) in Turkey were used. Then, a pool of 46 items was developed. It was ensured that there were at least two items measuring the same feature in the item pool and the items were distributed in a balanced way to the sub-dimensions existing in the literature. A 5-point likert type scale ranging from (1) never to (5) always was used for measurement. The numerical values were presented for each item to support easy tracking. Considering the cognitive levels of fourth-grade students, the number of words for each item kept limited to ten words (Y1lmaz $\&$ Korkmaz, 2017). The increase in scores is meant to increase in students' perceptions of social justice in their classrooms. 
Second stage: Based on the related literature (Bates, 2006; Fraser, 2001; Karacan et al., 2015), the PSJES was consisted of three factors: participatory justice, recognitional justice and distributive justice.

Third stage: Creating a valid and reliable scale requires a thorough examination of each statement for meaning, content and clarity. For the purpose of the face and the content validity, four field specialists, a scale development specialist, two classroom teachers and two language specialists provided their knowledge and expertise for the evaluation of the item pool. Each expert rated each item as essential, essential but needs to be corrected or not essential. Based on the experts' evaluations, seven items were deleted from the draft scale, several items were rewritten and a 39-item scale was created.

Fourth stage: After the final version of the scale was obtained, a legal permission for the inclass applications of the scale was provided from the Ministry of National Education in Turkey. The instrument was applied to 20 fourth-grade students to determine the clarity, comprehensibility and applicability of each item. Students responded to the scale in their classrooms and stated that each question is clear and understandable. Therefore, no further changes were made.

Fifth stage: This stage included two phases: exploratory and confirmatory factor analyses. A total of 150 students and 325 students were participated in the first and the second phases of the study, respectively. After obtaining the legal permission, the primary schools volunteering for participation were visited; and the necessary information was provided to the school administrators and the teachers. Before the applications, the students were informed about the study, voluntary nature of their participation, the absence of any grading and the duration of the application. The data was collected by the first author. The students were responded to the instrument in their own classrooms. During the implementation, the first author presented in the classroom. The completion of the instrument took approximately 20 minutes.

\section{Data Analysis}

Following the data collection process, first, the data were examined for extreme values and missing data. No extreme values or any pattern in missing values were detected. Because parametric tests in statistical analysis require normal distribution for higher reliability (Bursal, 2017), the distribution of the data was also examined using skewness and kurtosis values. In terms of normality, skewness and kurtosis values between +1 and -1 are considered excellent while values between -2 and +2 are considered acceptable (George \& Mallery, 2016). In this study, the skewness and the kurtosis values were satisfactory (skewness: -.483 and .198; and kurtosis -.243 and .394, for exploratory and confirmatory data, respectively). Therefore, the distributions of the data at two time points were considered normal.

Following the normality test, Kaiser-Meyer Olkin (KMO) coefficient and Bartlett's test of sphericity were examined to determine whether the data were suitable for factor analysis. KMO value greater than .60 and Bartlett's test of sphericity lower than .05 are considered satisfactory (Büyüköztürk, 2008).

Factor analysis is a multivariate statistic for obtaining few variables with a large number of identifiable features and the construct validity of the scales can be examined using factor analysis (Büyüköztürk, 2002). In this study, while performing exploratory factor analysis, direct oblimin technique, one of the horizontal rotation techniques, was used to determine whether 
there is a relationship between the factors. Since the relation of the factors with each other was detected under 0.30, varimax rotation, one of the vertical rotation techniques, was used in the factor analysis. In the case of multi-factor structures, the lower limit of the total variance explained by the related items is recommended to be at least $40 \%$ (DeVellis, 2017). In multifactor scales, each factor needs to have at least three items and contribute a minimum of 5\% to the total variance (Costello \& Osborne, 2005). In the correlation matrix, the items are expected to correlate with each other sufficiently, which requires the presence of inter-correlation values greater than 0.30 (Sherbourne \& Stewart, 1991).

Following EFA, Confirmatory Factor Analysis (CFA) was used to determine whether the data fit adequately to the model emerged from the EFA. For evaluating goodness of fit, Garver and Mentzer (1999) recommended the Tucker Lewis Index (TLI), the Comparative Fit Index (CFI) and the Root Mean Square Error of Approximation (RMSEA). For a good fit, the score of RMSEA should be less than .05 (Schermelleh-Engel, Moosbrugger, \& Müller, 2003). Comparative Fit Index (CFI) and Tucker Lewis Index (TLI), ranging from 0 to 1, should be equal or greater .90 for acceptable fit (Garver and Mentzer, 1999). On the other hand, Schermelleh-Engel et al (2003) suggest that CFI and NNFI indexes should be equal or higher than .95 . However, CFA results may not work well with effects of some factors including estimators, distributions and sample sizes (Hu \& Bentler, 1999; Schermelleh-Engel et al., 2003). After first order analysis, second order CFA was conducted to examine whether factors are combined under PSJES.

In addition to the validity studies, the reliability analyses were also performed. In statistical analyses, the internal consistency reliability is expected to be at least .70 (Cronbach, 1951). In this study, the reliability of the scale was determined by Cronbach alpha reliability analysis, and, also, $t$ values of $27 \%$ lower and upper groups were calculated for criterion related validity.

\section{RESULTS}

\section{Exploratory Factor Analysis (EFA)}

In the process of the EFA, first, KMO and Bartlett's test of sphericity calculated to determine whether the data are suitable for factor analysis. The results showed that KMO value was .77 and Bartlett's test result was significant $(p<.001)$. Then, using the varimax analysis, the determinant value was examined. The determinant value from correlation matrix was found to be .05 , indicating that there was no multicollinearity between items. Based on EFA findings, the items remaining at the lower limit of 0.30 and overlapping were removed from the scale and the analysis procedures were repeated for each item removal. Thus, 26 of the 39 items in the draft scale were discarded and the analysis was repeated for the remaining 13 items. The results showed that PSJES explained 52\% of total variance with a three-dimensional structure. The variance explanation rate calculated as $20 \%$ for the first factor, $16 \%$ for the second factor and $15 \%$ for the third factor (Table 2).

Table 2. Total Variance for PSJES

\begin{tabular}{crrcccc}
\hline Factor & \multicolumn{3}{c}{ Initial Eigen Values } & \multicolumn{3}{c}{ Sum of Rotated Square Loads } \\
& Total & Variance & Cumulative\% & Total & Variance & Cumulative\% \\
\hline 1 & 3.686 & 28.355 & 28.355 & 2.701 & 20.776 & 20.776 \\
2 & 1.853 & 14.254 & 42.608 & 2.061 & 15.850 & 36.626 \\
3 & 1.231 & 9.468 & 52.077 & 2.009 & 15.450 & 52.077 \\
4 & .953 & 7.329 & 59.406 & & & \\
\hline
\end{tabular}


According to the data presented in Table 3,13 items remaining on the scale were collected under three factors. The three sub-dimensions of the scale were named as Participatory Justice (P1, P2, P3, P4, P5 and P6), Recognitional Justice (R7, R8 and R9) and Distributive Justice (DR10, DR11, DR12 and DR13). Three items in the scale were reverse coded (DR10, DR11 and DR12). After explanatory factor analysis, the correlation coefficients of the items remaining in the scale were higher than 0.30 . Also, since the common factor variance ratios are greater than 0.10 , it is predicted that all the items make a sufficient contribution to the common variance of the factors.

Table 3. Exploratory Factor Structure for PSJES

\begin{tabular}{|c|c|c|c|c|c|c|}
\hline & Items & M & sd & $\mathrm{F} 1$ & $\mathrm{~F} 2$ & F3 \\
\hline P1 & $\begin{array}{l}\text { We comfortably present the shows (drama, theatre) that we } \\
\text { have prepared in the classroom. }\end{array}$ & 3,347 & 1,470 & .747 & & \\
\hline $\mathrm{P} 2$ & We freely read the essays we write in the class. & 3,680 & 1,397 & .726 & & \\
\hline P3 & Everyone in the class freely expresses their ideas. & 3,933 & 1,350 & 668 & & \\
\hline $\mathrm{P} 4$ & $\begin{array}{l}\text { My teacher makes various activities for everyone to } \\
\text { participate in class. }\end{array}$ & 3,580 & 1,439 & .613 & & \\
\hline P5 & My teacher encourages us to use our rights. & 4,007 & 1,308 & .568 & & \\
\hline P6 & $\begin{array}{l}\text { Everyone expresses their opinions while making a decision in } \\
\text { the classroom. }\end{array}$ & 4,220 & 1,098 & .547 & & \\
\hline $\mathrm{R} 7$ & My teacher loves me even if my clothes are not beautiful. & 4,260 & 1,343 & & .849 & \\
\hline $\mathrm{R} 8$ & My teacher loves me even if the things on me are dirty. & 4,013 & 1,405 & & .823 & \\
\hline R9 & $\begin{array}{l}\text { My teacher even loves the students who don't know the } \\
\text { answers to the questions. }\end{array}$ & 4,020 & 1,303 & & .470 & \\
\hline DR10 & $\begin{array}{l}\text { My teacher gives some of my classmates more opportunity to } \\
\text { talk. }\end{array}$ & 3,673 & 1,388 & & & .780 \\
\hline DR11 & My teacher smiles at some students more while talking. & 3,733 & 1,288 & & & .691 \\
\hline DR12 & My teacher only rewards some students. & 3,873 & 1,343 & & & .625 \\
\hline DR13 & My teacher congratulates everyone who does the right thing. & 3,860 & 1,182 & & & .568 \\
\hline
\end{tabular}

\section{Confirmatory Factor Analysis (CFA)}

Confirmatory factor analysis was used to confirm the factor structure determined by EFA. The goodness of fit values obtained from the CFA were compared against the criteria in the literature (Garver \& Mentzer, 1999; Schermelleh-Engel et al., 2003). Because the ratio of chi-square to degree of freedom is lower than 5 and satisfactory, other fit indices of the model were examined. The results showed that the data fit well with the model emerged from the EFA (Table 4). The first order CFA model was presented in Figure 1. The factor loadings of the items in the model varied between .47 and .55; and the error variances ranged from .48 to .68.

Table 4. CFA Fit Indices of the Model for PSJES

\begin{tabular}{lccc}
\hline Fit indices & Model data & Good-fit & Acceptable fit \\
\hline$\chi 2 / \mathrm{df}$ & 1.89 & $0 \leq \chi 2 \mathrm{df} \leq 2$ & $2 \leq \chi 2 \mathrm{df} \leq 3$ \\
RMSEA & 0.05 & $0 \leq \mathrm{RMSEA} \leq .05$ & $.05 \leq \mathrm{RMSEA} \leq .08$ \\
SRMR & 0.08 & $0 \leq \mathrm{SRMR} \leq .05$ & $0.05 \leq \mathrm{SRMR} \leq .10$ \\
NNFI (TLI) & 0.91 & $.97 \leq \mathrm{NFI} \leq 1.00$ & $.90 \leq \mathrm{NFI} \leq 97$ \\
GFI & 0.95 & $.95 \leq \mathrm{GFI} \leq 1.00$ & $.90 \leq \mathrm{GFI} \leq .95$ \\
AGFI & 0.92 & $.90 \leq \mathrm{AGFI} \leq 1.00$ & $.85 \leq \mathrm{NFI} \leq .90$ \\
CFI & 0.93 & $.97 \leq \mathrm{CFI} \leq 1.00$ & $.90 \leq \mathrm{CFI} \leq 97$ \\
\hline
\end{tabular}




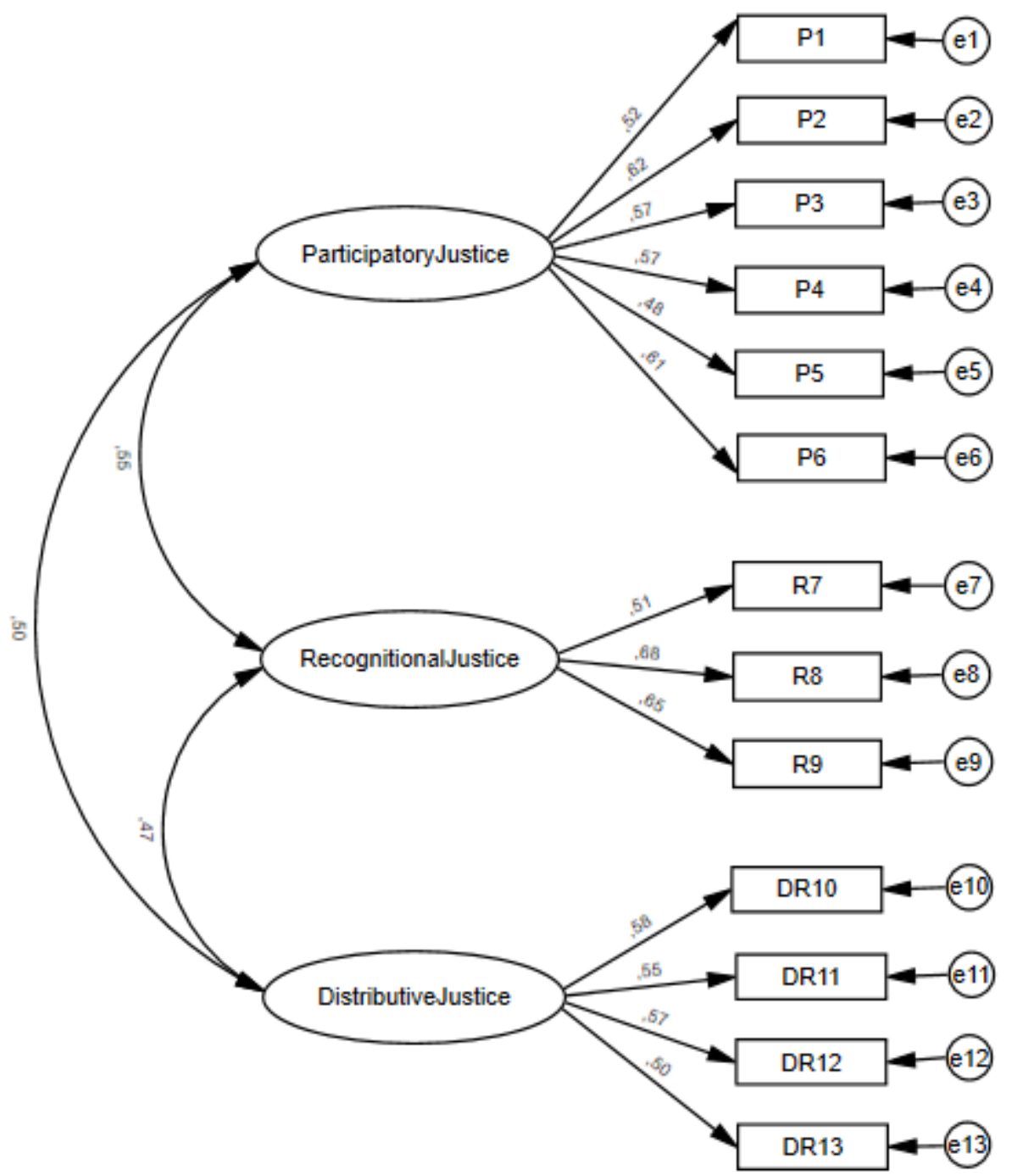

Figure 1. The First Order CFA for the PSJES

The second order CFA model showed that the three dimensions that emerged from EFA and the first level CFA were combined in a higher dimension (Table 5). The fit indices for the first and the second order CFA were acceptable in terms of $\chi 2 / \mathrm{df}$, RMSEA, GFI, AGFI, SRMR, NNFI, and CFI indexes.

Table 5. Second Order CFA Fit Index Test of the Model

\begin{tabular}{lllllll}
\hline$\chi 2 / \mathrm{df}$ & RMSEA & SRMR & NNFI & GFI & AGFI & CFI \\
\hline 1.86 & 0.05 & 0.08 & 0.91 & 0.95 & 0.92 & 0.93 \\
\hline
\end{tabular}

The second order CFA model was presented in Figure 2. The factor loadings of the items in the model varied between .65 and .76 . 


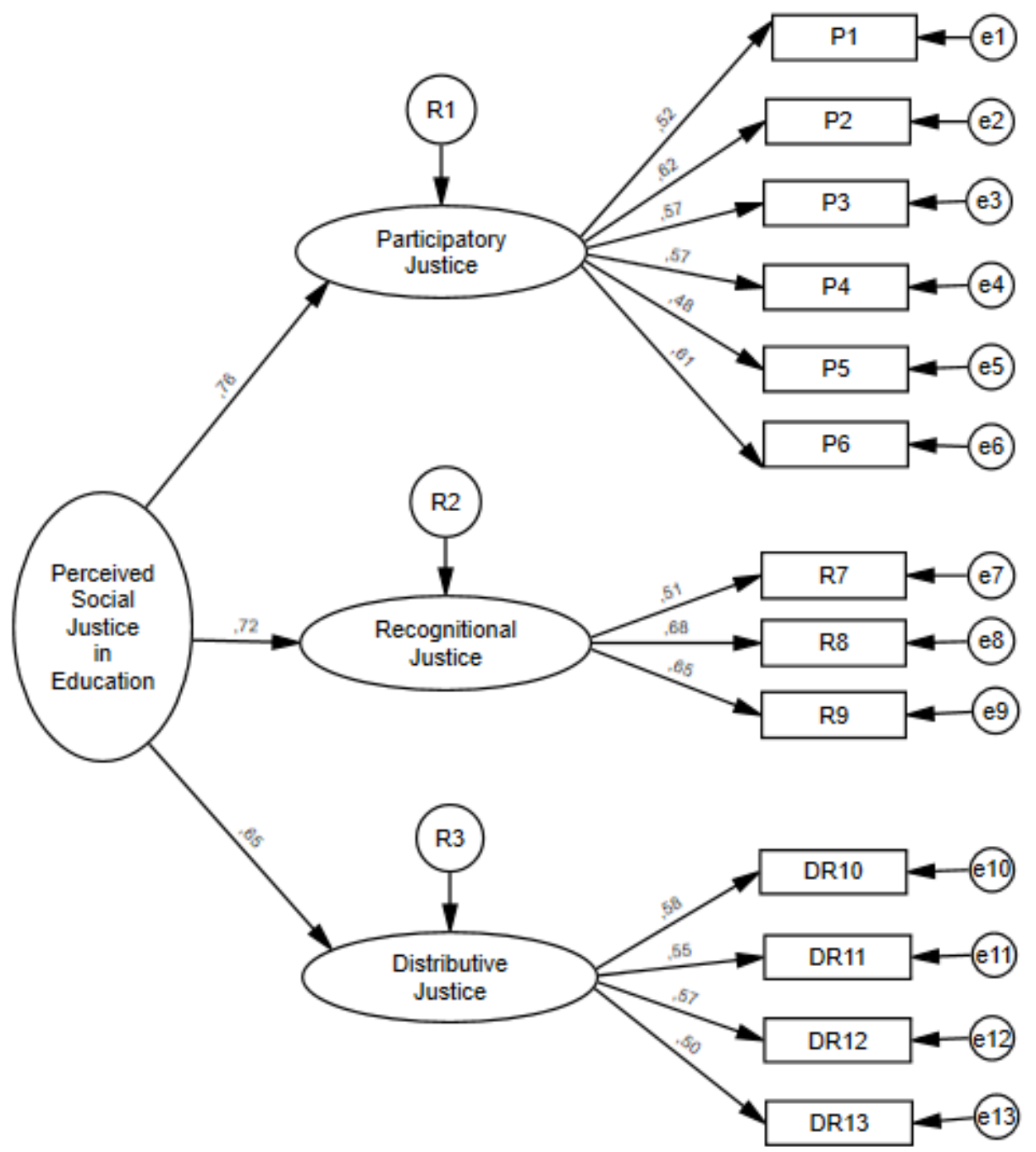

Figure 2. The Second Order CFA for the PSJES

\section{Reliability}

The internal consistency reliability of the scale was found to be .78 . The item-total test correlations varied between .32 and .49 . For testing criterion related validity, $t$ values of $27 \%$ lower and $27 \%$ upper groups were founded meaningful for all items $(p<.001)$.

\section{DISCUSSION}

The purpose of this research was to develop a valid and reliable scale measuring primary school students' perceptions of social justice in their classrooms. For this purpose, the related literature was reviewed and the opinions of primary school students and teachers were obtained to develop a draft scale. Based on the experts' opinions, several items were removed and the scale was applied for clarity and comprehensibility purposes. Following the content validity procedure, the data was collected from the fourth-grade students in Istanbul for EFA and CFA and reliability testing purposes. A 5-point Likert type measure, ranging from $1=$ never to $5=$ always was used for measurement. Finally, the Perceived Social Justice in Education Scale (PSJES) consisted of 3 factors and 13 items was developed. Three items are reversed coded. The sub-factors in the scale consistent with the literature were named as "participatory justice, 
distributive justice and recognizing justice". Using 5-point Likert type measurement, the lowest score that can be obtained from the scale is 13 and the highest score is 65 . An increase in the scores obtained from the scale indicates an increase in students' perceptions of social justice in their classrooms and vice versa.

There are some limitations of this study. First of all, the participants of this study were selected from Istanbul only. Although the city has a cosmopolitan structure that has a vast capacity for representing many regions of Turkey, more studies are needed in different regions and diverse cultures. Secondly, a quantitative research method was used in this study. Future studies designed with a mixed or a qualitative research approach is needed for an in-depth analysis of the concept of social justice. For example, in their study, Ibret et al. (2018) founded 149 different metaphors related to the concept of democracy expressed by the participating prospective teachers. A similar future research can dwell into the investigation of social justice metaphors of teachers and students in educational environments.

As indicated earlier, theory and research suggest a connection between students' perceptions of social justice and their social, emotional and academic outcomes in educational environments (Furman \& Shields, 2005; Sandage et al., 2014). Therefore, more research, especially in developing countries, is needed to better understand the role of perceived social justice on students' social, psychological, and educational outcomes and the potential interactions among the related variables.

In their research, Torres-Harding et al. (2011) developed a Social Justice Scale for graduate and undergraduate students. Karacan et al. (2015) developed Social Justice Scale to measure high school teachers' level of performing social justice in schools. Cirik (2015) analyzed the psychometric characteristics of the Turkish version of Social Justice Scale. Özdemir and Kütküt (2015) developed Social Justice Leadership Scale to measure the social justice leadership behaviours of school principals. However, to our knowledge, there has not been any research inquiring primary school students' perceived social justice in educational environments and there is not enough studies on social justice practices in education. In this scope, PSJES can be adopted by researchers, school administrators, and teachers aiming at studying social justice in primary school environments. In future studies, the PSJES can be adapted for different developmental levels, especially for early childhood level. In addition, considering that social injustice may occur more for special students, the related research in the field of special education is needed. Especially, in integrated classrooms, raising the awareness of students about the value of social justice in their classrooms is critical to create a more humane environment for all.

\section{Ethical Text}

In this article, research and publication ethics rules are followed. The responsibility of any violation regarding the article belongs to the author(s).

\section{REFERENCES}

Bates, R. (2006). Educational administration and social justice. Education, Citizenship and Social justice, 1(2), 141-156. https://doi.org/10.1177/1746197906064676

Bursal, M. (2017). SPSS ile temel veri analizleri. Anı Yayıncılık.

Büyüköztürk, Ş. (2002). Faktör analizi: Temel kavramlar ve ölçek geliştirmede kullanımı. Kuram ve Uygulamada Ĕ̈itim Yönetimi, 32(32), 470-483. 
Büyüköztürk, Ş. (2008). Veri analizi el kitabl. Pegem Akademi.

Cirik, I. (2015). Psychometric characteristics of the Social Justice Scale's Turkish form and a structural equation modeling. Eurasian Journal of Educational Research, 61, 23-44. https://dx.doi.org/10.14689/ejer.2015.61.2

Cochran-Smith, M. (2004). Walking the road: Race, diversity and social justice in teacher education. Teachers College Press.

Connell, R. W., \& Connell, R. (1993). Schools \& social justice. Temple University Press.

Costello, A. B., \& Osborne, J. (2005). Best practices in exploratory factor analysis: Four recommendations for getting the most from your analysis. Practical Assessment, Research, and Evaluation, 10(1), 7. https://doi.org/10.7275/jyj1-4868

Cronbach, L. (1951). Coefficient alpha and the internal structure of tests. Psychomerika, 16(3), $297-334$. https://doi.org/10.1007/BF02310555

DeVellis, R. F. (2017). Ölçek geliştirme: Kuram ve uygulamalar. Nobel Akademik Yayıncılık.

Fraser, N. (2001). Social justice in the knowledge society: Redistribution, recognition, and participation. Heinrich Böll Stiftung, 5, 1-13.

Fraser, N. (2007). Re-framing justice in a globalizing world. In T. Lovell (Ed.), (Mis)recognition, social inequality and social justice (pp. 17-35). Routledge.

Furman, G. C., \& Shields, C. M. (2005). How can educational leaders promote and support social justice and democratic community in schools? In W. A. Firestone \& C. Riehl (Eds.), A new agenda for research in educational leadership (pp. 119-137). Teachers College Press.

Garver, M. S., \& Mentzer, J. T. (1999). Logistics research methods: Employing structural equation modeling to test for construct validity. Journal of Business Logistics, 20(1), 33.

George, D., \& Mallery, P. (2016). IBM SPSS statistics 23 step by step: A simple guide and reference. Routledge.

Giroux, H. A. (1992). Language, difference, and curriculum theory: Beyond the politics of clarity. Theory into Practice, 31(3), 219-227. https://doi.org/10.1080/00405849209543546

Hu, L. T., \& Bentler, P. M. (1999). Cutoff criteria for fit indexes in covariance structure analysis: Conventional criteria versus new alternatives. Structural Equation Modeling: a Multidisciplinary Journal, 6(1), 1-55.

Ibret, B. Ü., Recepoğlu, E., Avcı, E. K., \& Recepoğlu, S. (2018). Perceptions of prospective teachers about the concept of "Democracy". Journal of History Culture and Art Research, 7(5), 421-441. https://doi.org/10.7596/taksad.v7i5.1763

Johnston, D. (2011). A brief history of justice (vol. 10). John Wiley \& Sons.

Karacan, H., Bağlıbel, M., \& Bindak, R. (2015). Okullarda sosyal adalet ölçeğinin geliştirilmesi: Geçerlik ve güvenirlik çalışması. Mustafa Kemal Üniversitesi Sosyal Bilimler Enstitüsü Dergisi, 12(31), 54-68.

Koçak, S., \& Bostancı, A. B. (2019). Sınıf yönetiminde sosyal adalet. Ankara Üniversitesi Eğitim Bilimleri Fakültesi Dergisi, 52(3), 917-944. https://doi.org/10.30964/auebfd.597200

Kolucki B., \& Lemish, D. (2011). Communicating with children: Principles and practices to nurture, inspire, excite, educate and heal. UNICEF.

Miller, D. (1999). Principles of social justice. Harvard University Press. Retrieved from https://www.jstor.org/stable/3232561?seq=1\#page_scan_tab_contents

OECD. (2012). Equity and Quality in Education: Supporting Disadvantaged Students and Schools. OECD Publishing.

Özdemir, M., \& Kütküt, B. (2015). Development of Social Justice Leadership Scale (SJLS): The validity and reliability study. Ahi Evran Üniversitesi Kırşehir Eğitim Fakültesi Dergisi, 16(3), 201-218.

Sandage, S. J., Crabtree, S., \& Schweer, M. (2014). Differentiation of self and social justice commitment mediated by hope. Journal of Counseling \& Development, 92(1), 67-74. https://doi.org/10.1002/j.15566676.2014.00131.x 
Schermelleh-Engel, K., Moosbrugger, H., \& Müller, H. (2003). Evaluating the fit of structural equation models: Tests of significance and descriptive goodness-of-fit measures. Methods of Psychological Research Online, 8(2), 23-74.

Speight, S. L., \& Vera, E. M. (2004). A social justice agenda: Ready, or not? The Counseling Psychologist, 32(1), 109-118. https://doi.org/10.1177/0011000003260005

Sherbourne, C. D., \& Stewart, A. L. (1991). The MOS social support survey. Social Science \& Medicine, 32(6), 705-714. https://doi.org/10.1016/0277-9536(91)90150-B

Tomul, E. (2009). İlköğretim okullarındaki sosyal adalet uygulamalarına ilişkin yönetici görüşleri. Eğitim ve Bilim Dergisi, 34 (152), 126-137.

Torres-Harding, S.R., Siers, B., \& Olson, B. D. (2012). Development and psychometric evaluation of the Social Justice Scale (SJS). American Journal of Community Psychology, 50, 77-88. https://doi.org/10.1007/s10464-011-9478-2

Turkish Ministry of National Education (2018). 2023 Education Vision. Retrieved from https://2023vizyonu.meb.gov.tr/doc/2023_VIZYON_ENG.pdf

Uluçınar, U., \& Aypay, A. (2018). An evaluation of the relationship between pre-service teachers' critical thinking dispositions and democratic values in terms of critical pedagogy. Journal of History Culture and Art Research, 7(3), 1-17. https://doi.org/10.7596/taksad.v7i3.1545

United Nations, Department of Economic and Social Affairs Disability (2007). Convention on the rights of persons with disabilities. Rethrieved from https://www.un.org/development/desa/disabilities/convention-on-therights-of-persons-with-disabilities.html

Wrigley, T. (2003). Is 'school effectiveness' anti-democratic? British Journal of Educational Studies, 51(2), 89112. https://doi.org/10.1111/1467-8527.t01-4-00228

Wrigley, T. (2004). 'School effectiveness': The problem of reductionism. British Educational Research Journal, 30(2), 227-44. https://doi.org/10.1080/0141192042000195272

Yılmaz, M., \& Korkmaz, C. (2017). 1-5. Sınıf Türkçe ders kitaplarındaki metinlerin içerik açısından değerlendirilmesi. Mustafa Kemal Üniversitesi Sosyal Bilimler Enstitüsü Dergisi, 14 (38), 111-130. 


\section{Perceived Social Justice in Education Scale}

Dear Participants: There is no right or wrong answers for the statements provided below. You will not receive any grade for your participation in this research. Your responses will remain confidential, your teachers and friends will not see your paper and will not know what you have marked. Read the each statement carefully and circle only 1 (one) response from the options given on the right hand side. Thank you for your participation.

\begin{tabular}{|c|c|c|c|c|c|}
\hline \multirow{2}{*}{$\begin{array}{l}\text { Age: } \\
\text { We comfortably present the shows (drama, theatre) that we have prepared in the classroom. }\end{array}$} & \multirow[b]{2}{*}{ Never(1) } & \multirow[b]{2}{*}{$\operatorname{Rarely}(2)$} & \multicolumn{2}{|c|}{ Gender: } & \multirow[b]{2}{*}{ Always(5) } \\
\hline & & & Sometimes(3) & Often(4) & \\
\hline We freely read the essays we write in the class. & Never(1) & Rarely(2) & Sometimes(3) & Often(4) & Always $(5)$ \\
\hline Everyone in the class freely expresses their ideas. & Never(1) & Rarely(2) & Sometimes(3) & Often(4) & Always (5) \\
\hline My teacher makes various activities for everyone to participate in class. & Never(1) & $\operatorname{Rarely}(2)$ & Sometimes(3) & Often(4) & Always (5) \\
\hline My teacher encourages us to use our rights. & Never(1) & Rarely (2) & Sometimes(3) & Often(4) & Always (5) \\
\hline Everyone expresses their opinions while making a decision in the classroom. & Never(1) & $\operatorname{Rarely}(2)$ & Sometimes(3) & Often(4) & Always (5) \\
\hline My teacher loves me even if my clothes are not beautiful. & Never(1) & Rarely(2) & Sometimes(3) & Often(4) & Always(5) \\
\hline My teacher loves me even if the things on me are dirty. & Never(1) & Rarely(2) & Sometimes(3) & Often(4) & Always $(5)$ \\
\hline My teacher even loves the students who don't know the answers to the questions. & Never(1) & $\operatorname{Rarely}(2)$ & Sometimes(3) & Often(4) & Always (5) \\
\hline My teacher gives some of my classmates more opportunity to talk. & Never(1) & Rarely(2) & Sometimes(3) & Often(4) & Always(5) \\
\hline My teacher smiles at some students more while talking. & Never(1) & Rarely $(2)$ & Sometimes(3) & Often(4) & Always (5) \\
\hline My teacher only rewards some students. & Never(1) & $\operatorname{Rarely}(2)$ & Sometimes(3) & Often(4) & Always (5) \\
\hline My teacher congratulates everyone who does the right thing. & Never(1) & $\operatorname{Rarely}(2)$ & Sometimes(3) & Often(4) & Always (5) \\
\hline
\end{tabular}

Eğitimde Sosyal Adalet Algısı Ölçeği

Değerli Karılımcılar: Așağıdaki maddelere ilișkin doğru veya yanlıș cevap bulunmamaktadır. Bu çalıșmaya katılımınız sonucunda bir not almayacaksınız. Cevaplarını gizli kalacak, kağıdınızı öğretmenleriniz ve arkadaşlarınız görmeyecek ve ne işaretlediğinizi bilmeyecek. Her soruyu dikkatlice okuyarak yandaki seçeneklerden sadece 1 (bir) cevabı yuvarlak içine alınız. Katılımınız için teșekkürler.

\begin{tabular}{|c|c|c|c|c|c|}
\hline Sinif: & & & & insiyet: & \\
\hline 1 Hazırladığımız gösterileri (drama, tiyatro) sınıfta rahatça sunarız. & Hiçbir Zaman(1) & Çok az(2) & Bazen(3) & Çoğu Zaman(4) & Her Zaman(5) \\
\hline 2 Yazdığımız yazılanı sinıfta özgürce okuruz. & Hiçbir Zaman(1) & Çok az(2) & $\operatorname{Bazen}(3)$ & Çoğu Zaman(4) & Her Zaman(5) \\
\hline 3 Sinıfta herkes fikirlerini özgürce anlatır. & Hiçbir Zaman(1) & Çok az(2) & $\operatorname{Bazen}(3)$ & Çoğı Zaman(4) & Her Zaman $(5)$ \\
\hline 4 Öğretmenim herkesin derse katılması için çeșitli etkinlikler yapar. & Hiçbir Zaman(1) & Çok az(2) & Bazen(3) & Çoğu Zaman(4) & Her Zaman(5) \\
\hline 5 Öğretmenim haklarımızı kullanmamız için bizi destekler. & Hiçbir Zaman(1) & Çok az(2) & $\operatorname{Bazen}(3)$ & Çoğu Zaman(4) & Her Zaman(5) \\
\hline 6 Sinıfta karar alınırken herkes fikrini söyler. & Hiçbir Zaman(1) & Çok az(2) & $\operatorname{Bazen}(3)$ & Çoğu Zaman(4) & Her Zaman(5) \\
\hline 7 Kıyafetlerim güzel olmasa da öğretmenim beni sever. & Hiçbir Zaman(1) & Çok az(2) & Bazen(3) & Çoğu Zaman(4) & Her Zaman(5) \\
\hline 8 Üzerim kirli olsa da öğretmenim beni sever. & Hiçbir Zaman(1) & Çok az(2) & Bazen(3) & Çoğı Zaman(4) & Her Zaman(5) \\
\hline 9 Öğretmenim soruları doğru cevaplayamayan öğrencileri de sever. & Hiçbir Zaman(1) & Çok az(2) & Bazen(3) & Çoğu Zaman(4) & Her Zaman(5) \\
\hline 0 Öğretmenim bazı arkadașlarıma daha çok söz hakkı verir. & Hiçbir Zaman(1) & Çok az(2) & $\operatorname{Bazen}(3)$ & Çoğu Zaman(4) & Her Zaman(5) \\
\hline 1 Öğretmenim konușurken bazı öğrencilere daha çok gülümser. & Hiçbir Zaman(1) & Çok az(2) & $\operatorname{Bazen}(3)$ & Çoğu Zaman(4) & Her Zaman(5) \\
\hline 2 Öğretmenim sadece bazı öğrencileri ödüllendirir. & Hiçbir Zaman(1) & Çok az(2) & $\operatorname{Bazen}(3)$ & Çoğu Zaman(4) & Her Zaman(5) \\
\hline 3 Öğretmenim doğru işler yapan herkesi tebrik eder. & Hiçbir Zaman(1) & Çok az(2) & Bazen(3) & Çoğu Zaman(4) & Her Zaman(5) \\
\hline
\end{tabular}

"International Journal of New Approaches in Social Studies - IJONASS" is licensed under a Creative Commons Attribution-NonCommercial-ShareAlike 4.0 International License. 